\title{
Using Vertical Electrical Soundings for Characterizing Hydrogeological and Tectonic Settings in Deir El-Adas Area, Yarmouk Basin, Syria
}

\author{
Walid AL-FARES \\ Atomic Energy Commission, Department of Geology, Damascus, Syria; \\ e-mail: cscientific2@aec.org.sy
}

\begin{abstract}
The present study is aimed at characterizing the subsurface geological and tectonic structure in Deir El-Adas area, by using Vertical Electrical Sounding survey (VES) and hydrogeological investigations, in order to determine the causes of the failure for the majority of the wells drilled in the area. The survey data was treated in three different approaches including direct VES inversion, pseudo-2D method and horizontal profiling, in order to maximize the reliability of the data interpretation. The results revealed the presence of a local faulted anticline structure at the top of the Paleogene formation, underneath the basaltic outcrops where Deir El-Adas village is situated. The appearance of this subsurface anticline structure has complicated the local hydrogeological situation, and most likely led to limitation of the groundwater recharge in the area. Moreover, the performed piezometric and discharge maps indicated the presence of a notable groundwater watershed, in addition to feeble water productivity of the wells drilled adjacent to Deir ElAdas, mostly related to the subsurface geological and tectonic settings in the area.
\end{abstract}

Key words: VES survey, hydrogeological investigations, Yarmouk Basin, Deir El-Adas, Syria.

Ownership: Institute of Geophysics, Polish Academy of Sciences;

(c) 2016 Al-Fares. This is an open access article distributed under the Creative Commons Attribution-NonCommercial-NoDerivs license,

http://creativecommons.org/licenses/by-nc-nd/3.0/. 


\section{INTRODUCTION}

Syria is considered to be one of the countries that suffer from a deficit in water resources in most of the hydrogeological basins, especially in Yarmouk Basin. The increasing demand for groundwater emerged as a result of the climatic conditions prevailing during the last three decades in the region, and the high growth of population as well as the agricultural and industrial needs. Moreover, the high demand for water supply has led to hundreds of wells being drilled all over the country.

The Yarmouk Basin extends over about $6730 \mathrm{~km}^{2}$, including $1000 \mathrm{~km}^{2}$ located within the northern part of Jordan. The population is estimated at more than one million inhabitants.

The geological and hydrogeological studies in the basin have started since the mid-nineteenth century. These studies aimed at identifying the geological and tectonic framework of the basin. The French geologists were the pioneers who carried out a morphological description of the basaltic outcrops in the region (Dubertret 1929). The Soviet geological studies which started in Syria in 1958 were focused on comprehensive geological and morphological surveys throughout the country. These studies allowed establishing several geological maps of Syria (Ponikarov 1963), which were used later as a basis in the following hydrogeological studies. In addition, more detailed works were performed by Russian Selkhozprom Export team in 1982, which fulfilled a detailed geological and hydrogeological surveys through Yarmouk Basin. The primary outcome of their works, from hydrogeological point of view, was the distinction of the basaltic groundwater aquifers. They found out that most of groundwater aquifers in the basin are non-homogenous horizontally and vertically in terms of hydraulic permeability and conductivity. With respect to Syrian studies in Yarmouk Basin, many works have been carried out including geological, geophysical, and hydrogeological studies (Safadi 1956, Bajbouj 1982, Chouker 1986). Recent efforts for characterizing the basaltic and Paleogene aquifers were introduced by Kattan (1995) and Charideh and Jubeli (2001). They have implemented two separated studies in Yarmouk Basin using environmental isotope and geochemical investigations. Their results have indicated that the major part of the basaltic groundwater recharge comes from the direct infiltration of precipitation, and they indicated also the role of faults and fractures in the movements of groundwater through gulches and water flats as dams. Nevertheless, most of the previous studies that were carried out in the Yarmouk Basin were performed on a large scale covering the whole basin and did not address to explain precisely some local hydrogeological phenomena that characterize the basaltic medium.

The objective of the present study is to characterize the subsurface geological and tectonic structure in Deir El-Adas area, by using Vertical Electri- 
cal Sounding survey (VES) and hydrogeological investigations, in order to evaluate the basaltic groundwater aquifers and consequently determine the causes of the failure for the majority of the wells drilled in the studied area. Accordingly, using geophysical techniques could be a vital tool to explore and interpret some distinctive hydrogeological features, which are wildly common in inhomogeneous groundwater aquifers such as the basaltic environments. The electrical resistivity method is one of the geophysical techniques applied commonly in hydrogeological researches (Astier 1971, Kelly and Mares 1993, Broadbent and Callander 1991, Reynolds 1997, AlBouy et al. 2001). This method was used in a large number of studies for solving many critical hydrogeological issues, including characterization of groundwater aquifers, determination of drilling wells locations or subsurface structures detection. (Yadav et al. 1997, Bernard et al. 1998, Guerin et al. 2001, Sandberg et al. 2002, Wilson et al. 2006, Al-Fares 2011, Zarroca et al. 2011, Vouillamoz et al. 2012).

\section{GEOLOGICAL AND TECTONIC SETTING}

The study area is situated within the western volcanic scope of Yarmouk Basin, which is sited in the south-western part of Syria, and covers a total area of $900 \mathrm{~km}^{2}$. The topographic elevation is quite simple and it ranges between 650 to $850 \mathrm{~m}$ a.s.l. (Fig. 1). The basaltic outcrops of the Quaternary and Neogene cover $95 \%$ of Yarmouk Basin, with thickness ranging from tens to several hundred meters. These deposits are associated with the presence of wide range of volcanoes scattered over the entire basin, relating to the tectonic activities of the Dead Sea Faults System (Ponikarov 1963). The basalts of the lower Quaternary $\left(\beta_{1} Q_{1}\right)$ are covering the major parts of the study area, and it is composed of a medium-hard to a crisp basaltic rocks. Generally, layers of clays with 1.5 to $2.5 \mathrm{~m}$ thickness separate these rocks. The recent Quaternary $\left(\beta_{2} Q_{4}\right)$ consists of massive and alkaline basaltic rocks, which are hard and fractured. The rest of the basalts, which belong to the midQuaternary $\left(\beta Q_{2}\right)$, cover the west parts of study area and represent subalkaline basalts. Soils and clay deposits with different thickness, which result from erosion and weathering processes, cover the basaltic outcrops. The thicknesses of these recent deposits vary from several centimeters to tens of meters, forming fertile agricultural soils. On the other hand, the volcanic outcrops of Neogene age $(\beta N)$, outcropping in the studied area, are composed mainly of alterated basalts punctuated by clay formation with different thicknesses. Conversely, the sedimentary Paleogene formations do not outcrop in the region because they are completely covered by the Quaternary and Neogene basalts. The thickness of the Paleogene formations is estimated and to be at about $400 \mathrm{~m}$ (Ponikarov 1963). 


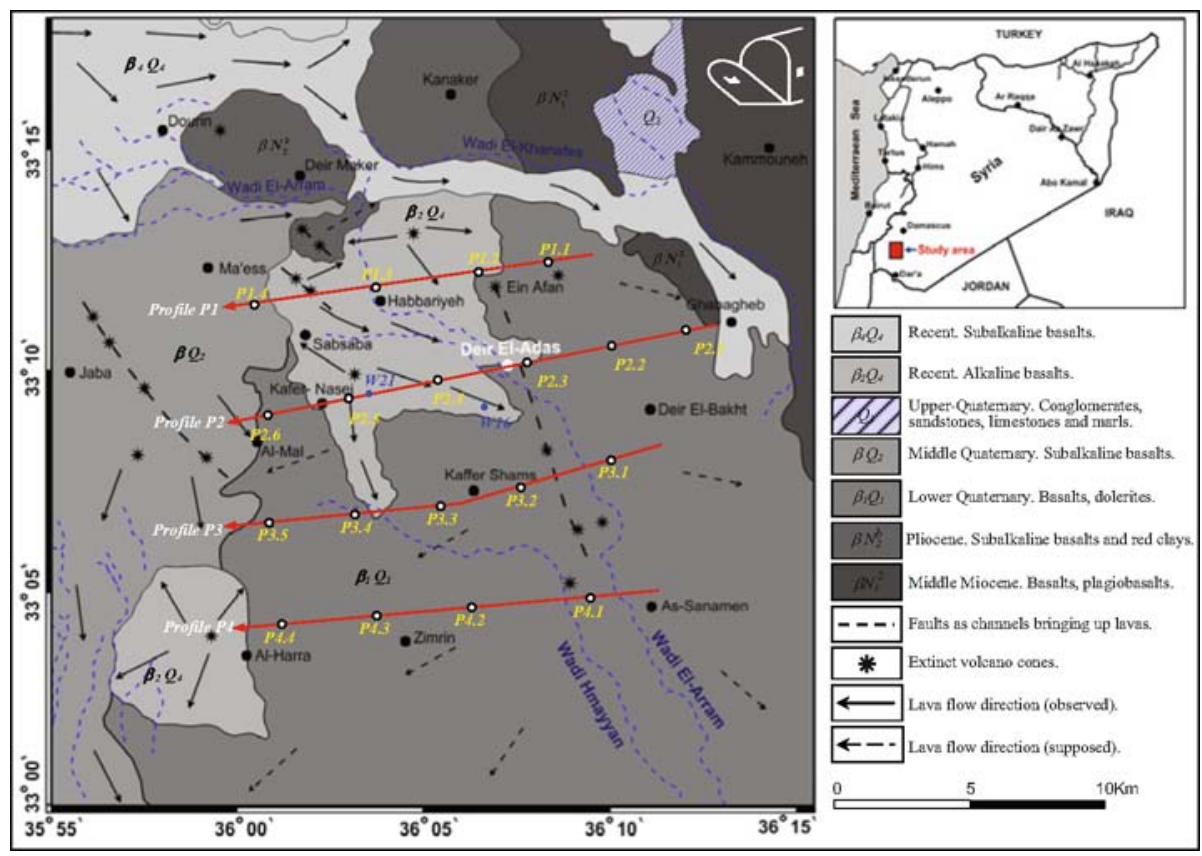

Fig. 1. Geological map of the study area (after Ponikarov 1963), showing the locations of the measuring vertical electrical soundings (VES) profiles, where $(P x . x)$ is a VES point, W21 and W16 are boreholes.

Tectonically, previous studies, which were carried out by Russians in Yarmouk Basin, revealed many tectonic lineaments such as faults, fractures and volcanic dykes (Ponikarov 1963, Selkhozprom Export 1982). In fact, through the geological map of the study area, a set of subsurface faults is observed and they are obviously affecting the sedimentary formations underneath the basalts. A set of similar and parallel valleys, like El-Arram and Hamyyan, are aligned with the general direction of the subsurface faults. Moreover, most of the streams in the north west of the study area flow almost along straight paths as well, and this could be referred to the presence of fractured zones through the basalts.

\section{HYDROGEOLOGICAL SETTING}

Depending on the geographic and topographic situation, an inhomogeneous rainfall system is prevailing in Yarmouk Basin. In the north-western margin with high elevations (Hermon Mount), the rainfall rates reach up to more than $1000 \mathrm{~mm} / \mathrm{y}$, while these values vary in the central and southern parts between 200 and $400 \mathrm{~mm} / \mathrm{y}$. In general, the annual average rainfall in Yarmouk Basin is proximately $350 \mathrm{~mm} / \mathrm{y}$. From hydrogeological point of view, 
the basaltic lava resulting from intensive and successive volcanic activities is characterized by the presence of several groundwater aquifers at different depths. However, other volcanic formations are quite poor in terms of forming reliable aquifers. Moreover, it has been noticed that the presence of groundwater aquifers is depending on the recharge and discharge in the area on the one hand and the heterogeneity of the permeability and storage in the horizontal and vertical levels on the other hand. According to the Russian investigations (Salkhozbrom Export 1982), most of the groundwater resources in the region are present in the lower Quaternary and upper Neogene, where aquifers can be classified as follows:

- Aquifers of recent and medium Quaternary basalts, which are shallow and have low general water productivity.

- Aquifers of lower Quaternary, which represent important local aquifers resources in the area.

- Aquifers of the upper Neogene basalts, which are characterized by high groundwater productivity in the basin.

The clay layers that separate the basaltic lava play a major role as impermeable barriers. This explains the emergence of many natural springs through the basaltic lava margins, which flow during the rainfall season feeding the local streams and valleys. Generally, most of the basaltic aquifers exist at different levels ranging from 400 to $700 \mathrm{~m}$ a.s.l. in the study region. Thickness of aquifers varies between 50 and $100 \mathrm{~m}$ (Salkhozbrom Export 1982). These aquifers are characterized by non-homogeneity horizontally and vertically, and may not have hydraulic links between them. The main recharges of these aquifers are drained from the direct rainfall, which infiltrate through the fractured basalts, and others come from the feeding of the regional groundwater flow. Nevertheless, there are other aquifers belonging to Paleogene and Cretaceous formations, but they are situated at deeper levels, which is out of the priorities of this study.

\section{VES AND HYDROGEOLOGICAL SURVEYS}

Nineteen vertical electrical sounding points, spread over four geoelectrical profiles, were acquired using (ACR-1) instrument (Fig. 1). The measuring profiles were nearly parallel and trending East-West. The length of profiles ranged between 15 and $20 \mathrm{~km}$ with a separate distance between them varied from 3 to $4 \mathrm{~km}$. Each profile included four to six VES, with 2 to $4 \mathrm{~km}$ as a separation interval distance between VES points, depending on the local conditions in the field. The Schlumberger configuration was used to obtain the apparent electrical resistivity, with $2000 \mathrm{~m}$ as maximum spacing between the $A B$ current electrodes $(A B / 2=1000)$. The locations and topographical levels of each sounding point were identified and localized by using a GPS 
device. The symbols P2.1 to P2.6 referred to the number of each sounding point. Table 1 summarizes the VES characteristics of the measuring profiles.

Table 1

Characteristics summary of the vertical electrical soundings (VES) measuring profiles in Deir El-Adas area

\begin{tabular}{|c|c|c|l|}
\hline Profile & No. VES points & Length $[\mathrm{km}]$ & \multicolumn{1}{|c|}{ Location } \\
\hline P1 & 4 & 15 & north of the study area \\
P2 & 6 & 20 & through Deir El-Adas \\
P3 & 5 & 17 & south of Deir El-Adas \\
P4 & 4 & 15 & south of the study area \\
\hline
\end{tabular}

The acquired VES apparent resistivity curves have been inverted using one dimension model including thickness and resistivity for each layer, by using master curves (Orellana and Mooney 1972). These procedures are automatically performed by using $1 \mathrm{D}$ inversion software, where approximate model is proposed to obtain a goodness fit between the measured and theoretical resistivity curves in order to achieve an optimum model solution (Dobrin 1976, Zohdy 1989).

In order to understand the geological and tectonic setting in the study area, Pichgin and Habibullaev methodology (Pichgin and Habibullaev 1985) has been applied on the VES field data. The aim of applying this methodology is to enable a 2D realistic vision of the local subsurface structures and, consequently, to evaluate the hydrogeological framework. It is worth to mention that this approach has been applied successfully in several locations in Syria in order to assess the subsurface geological and tectonic structures (e.g., Asfahani 2007a,b). The Pichgin and Habibullaev methodology is based on the following stages:

(i) The measured apparent resistivity curves are drawn with distance for all $A B / 2$ spacing along a geoelectrical profile. The intersection points between curves (called Non-Homogeneous Point, NHP) are determined taking into consideration that the scale is fitted vertically and horizontally. These points are represented with depth to perform 2D cross-sections (distance versus depth), where the depth of each points $(Z)$ is calculated according the following formula:

$$
Z=\frac{\left[\left(\frac{A B}{2}\right)_{i}+\left(\frac{A B}{2}\right)_{j}\right]}{2},
$$

where $(A B / 2)_{i}$ and $(A B / 2)_{j}$ are the half spacing between the electrodes $A$ and $B$ for the intersected curves. 
Table 2

Main characteristics of the surveyed wells in the study area

\begin{tabular}{|c|c|c|c|c|c|c|}
\hline $\begin{array}{l}\text { Well } \\
\text { code }\end{array}$ & $\begin{array}{c}\text { Longitude } \\
\qquad X\end{array}$ & $\begin{array}{c}\text { Latitude } \\
\qquad Y\end{array}$ & $\begin{array}{l}\text { Depth } \\
{[\mathrm{m}]}\end{array}$ & $\begin{array}{c}\text { Topographical } \\
\text { level } \\
\text { [m a.s.l.] }\end{array}$ & $\begin{array}{c}\text { Water level } \\
\text { [m a.s.l. }]\end{array}$ & $\begin{array}{c}\text { Discharge } \\
{[\mathrm{L} / \mathrm{s}]}\end{array}$ \\
\hline N1 & 36.0786 & 33.1539 & 230 & 787 & 638 & - \\
\hline N3 & 36.1457 & 33.2021 & 160 & 761 & 651 & - \\
\hline N7 & 36.0832 & 33.2083 & 180 & 834 & 707 & - \\
\hline N9 & 36.0737 & 33.1882 & 152 & 812 & 722 & - \\
\hline N10 & 36.0598 & 33.1728 & 170 & 830 & 700 & - \\
\hline N12 & 36.0306 & 33.1578 & 200 & 839 & 722 & - \\
\hline N13 & 35.9930 & 33.2198 & 105 & 906 & 861 & - \\
\hline N15 & 36.1718 & 33.1743 & 130 & 750 & 650 & - \\
\hline N16 & 36.1580 & 33.0532 & 150 & 646 & 592.8 & - \\
\hline N18 & 36.0714 & 33.0466 & 117 & 731 & 621 & - \\
\hline $\mathrm{N} 21$ & 36.1993 & 33.1927 & 90 & 724 & 664.1 & - \\
\hline $\mathrm{N} 22$ & 36.2246 & 33.1824 & 170 & 692 & 612 & - \\
\hline $\mathrm{N} 23$ & 36.1148 & 33.1598 & 120 & 740 & 659 & - \\
\hline N26 & 36.0326 & 33.1019 & 162 & 803 & 667 & - \\
\hline $\mathrm{N} 27$ & 36.0615 & 33.1004 & 160 & 777 & 647 & - \\
\hline $\mathrm{N} 28$ & 36.0923 & 33.1061 & 178 & 755 & 645 & - \\
\hline $\mathrm{N} 29$ & 36.1287 & 33.1048 & 175 & 696 & 621 & - \\
\hline N33 & 36.1659 & 33.1217 & 220 & 676 & 579 & - \\
\hline W3 & 36.1408 & 33.1938 & 100 & 755 & - & 2.0 \\
\hline W7 & 36.2091 & 33.1675 & 117 & 690 & - & 5.5 \\
\hline W8 & 36.1991 & 33.1558 & 107 & 690 & - & 3.3 \\
\hline W9 & 36.1929 & 33.1218 & 135 & 668 & - & 4.5 \\
\hline W10 & 36.2019 & 33.1166 & 125 & 669 & - & 3.3 \\
\hline W11 & 36.2377 & 33.1320 & 120 & 674 & - & 3.3 \\
\hline W13 & 36.1580 & 33.1644 & 135 & 726 & - & 4.0 \\
\hline W15 & 36.1574 & 33.1201 & 142 & 672 & - & 9.7 \\
\hline W16 & 36.1196 & 33.1469 & 176 & 727 & - & 2.8 \\
\hline W18 & 36.0908 & 33.1438 & 135 & 768 & - & 2.0 \\
\hline W20 & 36.0247 & 33.1263 & 132 & 860 & - & 3.3 \\
\hline W21 & 36.0636 & 33.1501 & 134 & 839 & - & 2.8 \\
\hline W25 & 36.0455 & 33.1619 & 115 & 850 & - & 1.5 \\
\hline W26 & 36.0397 & 33.2326 & 125 & 867 & - & 4.0 \\
\hline W27 & 36.0810 & 33.2002 & 115 & 851 & - & 5.5 \\
\hline
\end{tabular}


Table 2 (continuation)

\begin{tabular}{|c|c|c|c|c|c|c|}
\hline $\begin{array}{c}\text { Well } \\
\text { code }\end{array}$ & $\begin{array}{c}\text { Longitude } \\
X\end{array}$ & $\begin{array}{c}\text { Latitude } \\
Y\end{array}$ & $\begin{array}{c}\text { Depth } \\
{[\mathrm{m}]}\end{array}$ & $\begin{array}{c}\text { Topographical } \\
\text { level } \\
{[\mathrm{m} \text { a.s.1. }]}\end{array}$ & $\begin{array}{c}\text { Water level } \\
{[\mathrm{m} \text { a.s.l. }]}\end{array}$ & $\begin{array}{c}\text { Discharge } \\
{[\mathrm{L} / \mathrm{s}]}\end{array}$ \\
\hline W28 & 36.0355 & 33.1192 & 190 & 838 & - & 5.5 \\
W30 & 36.0250 & 33.1895 & 110 & 897 & - & 6.0 \\
W32 & 36.1184 & 33.1190 & 200 & 721 & - & 5.5 \\
W33 & 36.1121 & 33.1105 & 162 & 727 & - & 6.5 \\
W34 & 36.0306 & 33.0903 & 169 & 810 & - & 6.0 \\
W35 & 36.0441 & 33.0937 & 163 & 795 & - & 5.5 \\
W44 & 36.0791 & 33.0427 & 118 & 720 & - & 4.0 \\
W54 & 36.1749 & 33.0571 & 137 & 643 & - & 5.0 \\
W58 & 36.1194 & 33.0457 & 153 & 675 & - & 6.5 \\
W61 & 36.1120 & 33.0607 & 108 & 695 & - & 2.8 \\
W62 & 36.1024 & 33.0389 & 113 & 695 & - & 4.0 \\
W63 & 36.1160 & 33.0975 & 170 & 694 & - & 12.5 \\
W65 & 36.1237 & 33.0920 & 151 & 683 & - & 7.5 \\
W66 & 36.1027 & 33.1075 & 190 & 741 & - & 8.3 \\
W67 & 36.1422 & 33.0545 & 140 & 648 & - & 6.5 \\
W68 & 36.1355 & 33.0517 & 120 & 651 & - & 7.0 \\
W72 & 36.1002 & 33.2624 & 100 & 822 & - & 3.3 \\
W76 & 36.0449 & 33.2594 & 105 & 875 & - & 6.0 \\
W173 & 36.2145 & 33.2324 & 150 & 730 & - & 1.6 \\
\hline Aver- & & & 144.8 & 752.4 & 664.4 & 4.9 \\
age & & & & & & - \\
\hline
\end{tabular}

(ii) The intersection points are plotted as a function of depth $(z)$ to get a 2D pseudo- section $(x, z)$ for each geoelectrical profile.

Moreover, in order to evaluate the lateral variations of the resistivity and to trace the tectonic subsurface elements as faults and fractures, electrical resistivity profiling method was applied on the VES data. The method depends basically on drawing a group of $A B / 2$ spacing, for example $(A B / 2=3 \sim 15 \mathrm{~m})$, for all VES points along each measurement profile.

On the other hand, hydrogeological investigations were also performed through the studied area. The survey aimed to establish a piezometric and discharge maps for the available drilled wells in the area, in order to assess the regional hydrogeological framework, and to assist better interpretation of the geoelectrical results. The hydrogeological survey included more than 50 wells distributed all over the studied area. Locations, depths, water levels and discharge rates of the investigated wells are listed in Table 2. The topo- 
graphic elevations vary from 643 to $906 \mathrm{~m}$, with an average of $752 \mathrm{~m}$ a.s.1., while the depths range between 90 and $230 \mathrm{~m}$, with an average of $145 \mathrm{~m}$. The water levels differ between 579 and $861 \mathrm{~m}$, with $665 \mathrm{~m}$ a.s.l. as an average, whereas the discharge rates of the most wells range between 1.5 and $12.5(\mathrm{~L} / \mathrm{s})$ with general average of $4.9(\mathrm{~L} / \mathrm{s})$.

\section{RESULTS AND DISCUSSION}

The interpretation of the geoelectrical VES data was performed depending on the comprehensives geological knowledge of the study area, supported by true information from lithological columns of two wells drilled close to Deir El-Adas village (Figs. 1 and 2).

The $\mathrm{P} 2$ profile is located in a way that it crosscuts the main part of the study area, which constitutes the basic objective of this work and, therefore, its interpretation was of priority importance for achieving our results. However, the results of the other profiles will be discussed altogether in order to construct a comprehensive image of the geological and hydrogeological context. The P2 profile extends from Qabaghab to Al-Mal village, where 6 VES were carried out along its extension (Fig. 1).

Figure 3 shows the inverted 6 VES points performed along P2 profile, where the P2.1, P2.2, P2.3, and P2.6 points are located on the lower Quaternary basaltic rocks of $\left(\beta_{1} Q_{1}\right)$, while the points $\mathrm{P} 2.4$ and $\mathrm{P} 2.5$ are situated on the recent Quaternary basalts $\left(\beta_{2} Q_{4}\right)$, as shown in the geological map (Fig. 1). The curves of the first three VES points are quite similar and consist of a superficial layer with low resistivity values, ranging between 10 and

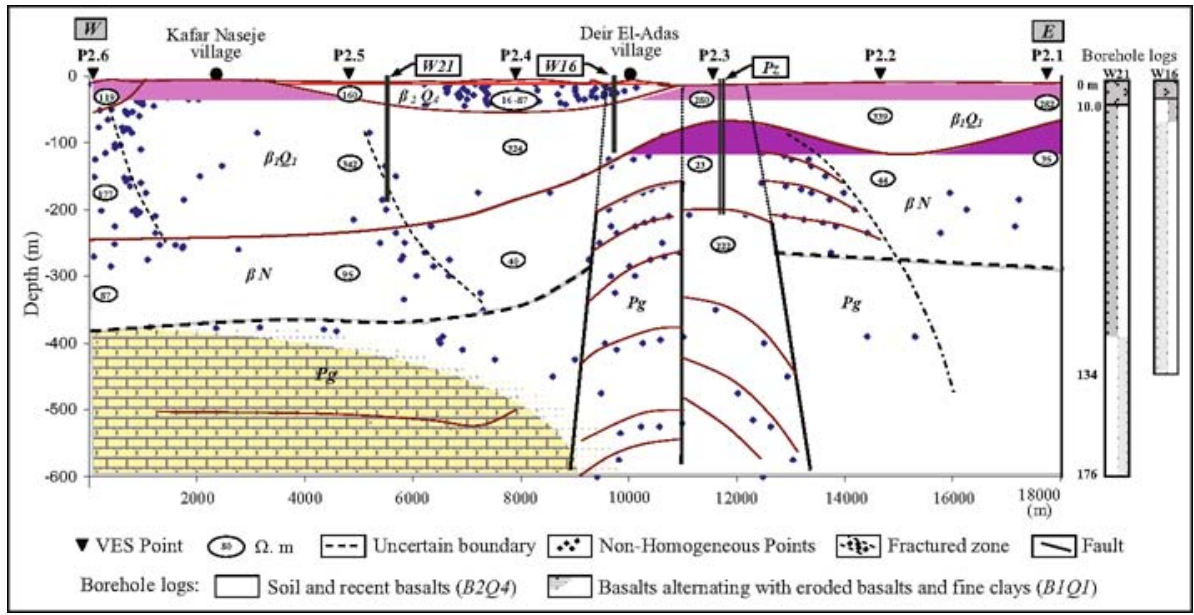

Fig. 2. Geoelectrical cross-section derived from vertical electrical soundings (VES) interpretation of $\mathrm{P} 2$ profile, where W21 and W16 are lithological logs of two boreholes, $P z$ is a failed water supply well. 

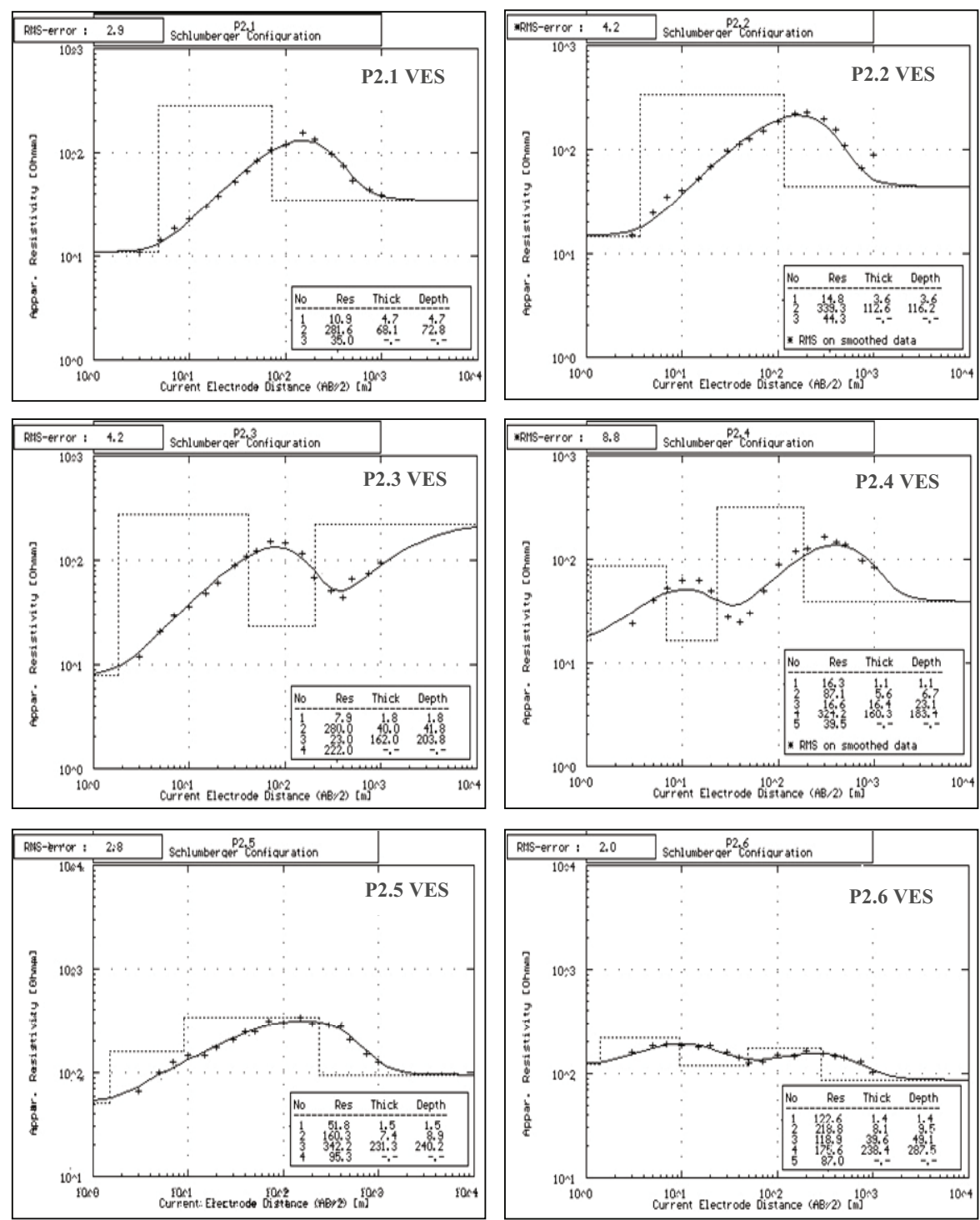

Fig. 3. Inversion of the vertical electrical soundings (VES) performed along P2 profile.

$15 \Omega \mathrm{m}$. This layer, which has a thickness of less than $5 \mathrm{~m}$, is related to agricultural soils resulting from the erosion processes of the basalts. The followed layer is characterized by relatively higher resistivity values, varying between 280 and $340 \Omega \mathrm{m}$, with a general thickness ranging from 40 to $100 \mathrm{~m}$. This layer is most likely related to basaltic formations of $\left(\beta_{1} Q_{1}\right)$. The 
third layer of the three VES points is marked by low resistivity values, varying between 23 and $35 \Omega \mathrm{m}$, with the thickness reaching $160 \mathrm{~m}$ only at the point P2.3, whereas the depth is unlimited at the points P2.1 and P2.2, as shown in Fig. 3. According to the resistivity values of the third layer, it is believed that it could be referred to a perched aquifer within the Neogene basaltic rocks $(\beta N)$. With regard to the last layer, which is restricted to the VES point $\mathrm{P} 2.3$, it has a resistivity value of $222 \Omega \mathrm{m}$, with $160 \mathrm{~m}$ thickness that corresponds to the boundary between the Neogene basalts and the upper Paleogene formation at about $200 \mathrm{~m}$ depth. This is confirmed by true information derived from a well drilled to the east of Deir El-Adas close to P2.3 VES point, denoted as $P z$ in Fig. 2. The curve of $\mathrm{P} 2.6$ point, which is located on the $\left(\beta_{1} Q_{1}\right)$ rocks, is composed of 5 layers (Fig. 3). The total thickness of these layers reaches up to $290 \mathrm{~m}$ and the resistivity values are alternating between 118 and $218 \Omega \mathrm{m}$. These layers are entirely related to lower Quaternary basalts of $\left(\beta_{1} Q_{1}\right)$ according to data obtained from the lithological logs of W21 and W16 (Fig. 2). The alternating resistivity values of the geoelectrical layers are mostly due to the successive basaltic lava of Al-Haraa and Al-Mal volcanoes. The last layer is most likely to belong to the Neogene basalts $(\beta N)$, where the resistivity values decrease to $87 \Omega \mathrm{m}$. Regarding the curves of the P2.4 and P2.5 points (Fig. 3), they consist of 5 geoelectrical layers due to the appearance of recent basaltic lava. The first three layers are referred to Quaternary basaltic rocks $\left(\beta_{2} Q_{4}\right)$, where the resistivity values range between 20 and $160 \Omega \mathrm{m}$ with $23 \mathrm{~m}$ thickness. These recent basaltic rocks are followed by a layer of $324 \Omega \mathrm{m}$ as a resistivity value and 180 to $230 \mathrm{~m}$ as a thickness range, belonging to $\left(\beta_{1} Q_{1}\right)$ basaltic rocks. It seems more likely that the last layer is attributed to the Neogene basalts $(\beta N)$, which is characterized by low relative resistivity of about $40 \Omega \mathrm{m}$. Consequently, it can be noticed that each of the Quaternary $\left(\beta_{1} Q_{1}\right)$ as well as the Neogene $(\beta N)$ basaltic rocks constitute distinguished and homogenous successive structures.

In order to enhance the interpretation of the inverted VES data and to clarify the subsurface structures in 2D vision, Pichgin and Habibullaev methodology has been applied. Figure 2 represents joint representation of the intersection points and the geoelectrical section outputting from the interpretation of the VES points of $\mathrm{P} 2$ profile. The geological interpretation of the Non-Homogeneous Points (NHP) is based on the way or the form of their distribution and extension. When the points are distributed in an irregular form, near the surface, this indicates a homogeneous lithological structure. However, when they are in a regular form, this reflects the presence of certain geological structure such as syncline, anticline, horizontal or dipping strata. If the points are arranged along lines going down with an angle, this refers to a tectonic fault or fracture. However, if they are located at shallow depths and arranged along dipping lines, this indicates the presence of inho- 
mogeneous lithological contact (Asfahani 2007b). Figure 2 infers a geological complex structure, through which the following features of substructures can be distinguished:

- A large group of non-inhomogeneous points in the central part near the surface, located between P2.3 and P2.5 VES points, seems to be placed irregularly and semi-horizontally. This structure is related to the recent basaltic outcrops $\left(\beta_{2} Q_{4}\right)$, where the thickness ranges from several meters in the margins to tens meters in the central parts, with resistivity values between 20 and $160 \Omega \mathrm{m}$.

a The $\left(\beta_{1} Q_{1}\right)$ basaltic rocks outcrop throughout the section, particularly at the points P2.1, P2.2, P2.3, and P2.6, while it is covered by recent basaltic formations in the rest of the points. The thickness of the $\left(\beta_{1} Q_{1}\right)$ basalts varies from 60 to $160 \mathrm{~m}$ at the points $\mathrm{P} 2.1, \mathrm{P} 2.2$, and $\mathrm{P} 2.3$, while it reaches up to $300 \mathrm{~m}$ in the western parts of the section (Fig. 2). The increase of the basalts thickness in the western parts is probably due to the vicinity of volcanic eruptions resources. The $\left(\beta_{1} Q_{1}\right)$ basaltic rocks are characterized by quite homogeneous resistivity values in all the measurement points, which vary from 280 to $340 \Omega \mathrm{m}$. Generally, most of the $\left(\beta_{1} Q_{1}\right)$ basalts were containing significant groundwater aquifers, but they have been exploited during the last three decades.

- The basalts of Neogene $(\beta N)$ are also recognized in all parts of the P2 cross-section with relatively large thickness, except the point P2.3, in which the thickness is about $100 \mathrm{~m}$. However, the lower boundary of the basalts is generally undefined due to the presence of an expected aquifer that locates between the base of the basalts and the underneath Paleagene formations. The resistivity values at the boundary range between 40 and $70 \Omega \mathrm{m}$, except for the point P2.3 where the boundary is obvious due to (i) the absence of the aquifer, and (ii) the presence of high contrast in resistivities between the basalts $(28 \Omega \mathrm{m})$ and Paleagene rocks $(224 \Omega \mathrm{m})$.

From tectonic point of view, the most important finding is the appearance of a local emerging anticline structure that is located in the central part of the section (Fig. 2). This remarkable structure seems to be affected by subvertical faults that deform the Paleogene rocks and the overlying basalts, underneath Deir El-Adas village. The presence of such a structure is mostly attributed to the absence or weakness of the groundwater aquifers at the top of the previously mentioned anticline structure. Besides, the faults affecting the Paleogene rocks as well as the influence of the volcanic eruptions possibly play a negative role on the hydrogeological setting (Salameh and $\mathrm{Al}$ Farajat 2007), because they redirect the regional groundwater flow coming from the north-west, thereby blocking the drainage of groundwater into Deir El-Adas region. 
Additionally, the electrical resistivity profiling method was applied on the VES data to identify the lateral variations of the resistivity pattern in order to assist tracing the tectonic subsurface elements such as faults and fractures. Figure 4 shows the interpretation of the electrical resistivity profiling along the $\mathrm{P} 2$ profile. The first group of electrodes spacing comprised $A B / 2=$ $3 \sim 15 \mathrm{~m}$, with penetrating depth assumed to be between 5 and $7 \mathrm{~m}$. The curves of this spacing group show superficial homogenous basaltic formations. The second and the third groups represent spacing of $A B / 2=$ 20 400 m, which corresponds to depths of 10 to $200 \mathrm{~m}$. Within the range of these depths, turning and intersection points were noticed at abscises of 6 and $12 \mathrm{~km}$ on the curves where the substructure becomes distinguishable (Fig. 4). This indicates to the presence of horizontal and inhomogeneous formations, which may reflect the existence of faults or probable lithological contrast in the central part of the section. This could be an additional evidence for the presence of the above-mentioned anticline structure, which represents the ultimate aim of this study. The last group of curves represents the spacing of $A B / 2=500 \sim 1000 \mathrm{~m}$, where the depths reach more than $400 \mathrm{~m}$. At this position, the heterogeneity becomes nearly indistinguishable as the depth increases, but the form of the general structure is still preserved.

With regard to the other VES profiles, Fig. 5 shows the interpretation of the geoelectrical pseudo-section of P1 profile, which depicts homogenous formations near the surface within the depth of 5-7 $\mathrm{m}$ in the western sector, while it infers the existence of a tectonic structure close to the P1.1 and P1.2 VES points. This structure, at the eastern sector of $\mathrm{P} 1$ profile, might be related either to faults or to some local volcanic activities of Ain Afaa and Tell Assobeh volcanoes. The P1 electrical resistivity profiling curves confirm the presence of this structure, particularly at the spacing of $A B / 2=20$ to $200 \mathrm{~m}$. It should be noted here that the lower boundary of the basaltic formations seems to be undefined due to the great thickness of these formations along the $\mathrm{P} 1$ profile.

With respect to the pseudo-section $\mathrm{P} 3$ profile, the interpretation results reveal a number of basaltic sequences that are different in thickness and extension (Fig. 6). One point of interest is the presence of a subvertical non homogenous zone with $80 \mathrm{~m}$ length and more than $200 \mathrm{~m}$ depth, located opposite to the P3.4 VES point. The presence of this distinctive zone could be related to a probable fault associated with Al-Hamyyan valley (Fig. 1). This finding has been demonstrated by the results obtained by the electrical resistivity profiling curves at a distance of $4000 \mathrm{~m}$ from the start point of $\mathrm{P} 3$ profile.

The pseudo-section $\mathrm{P} 4$ profile is characterized by two subvertical structures located between P4.1 and P4.3 (Fig. 7). One of these subvertical zones 


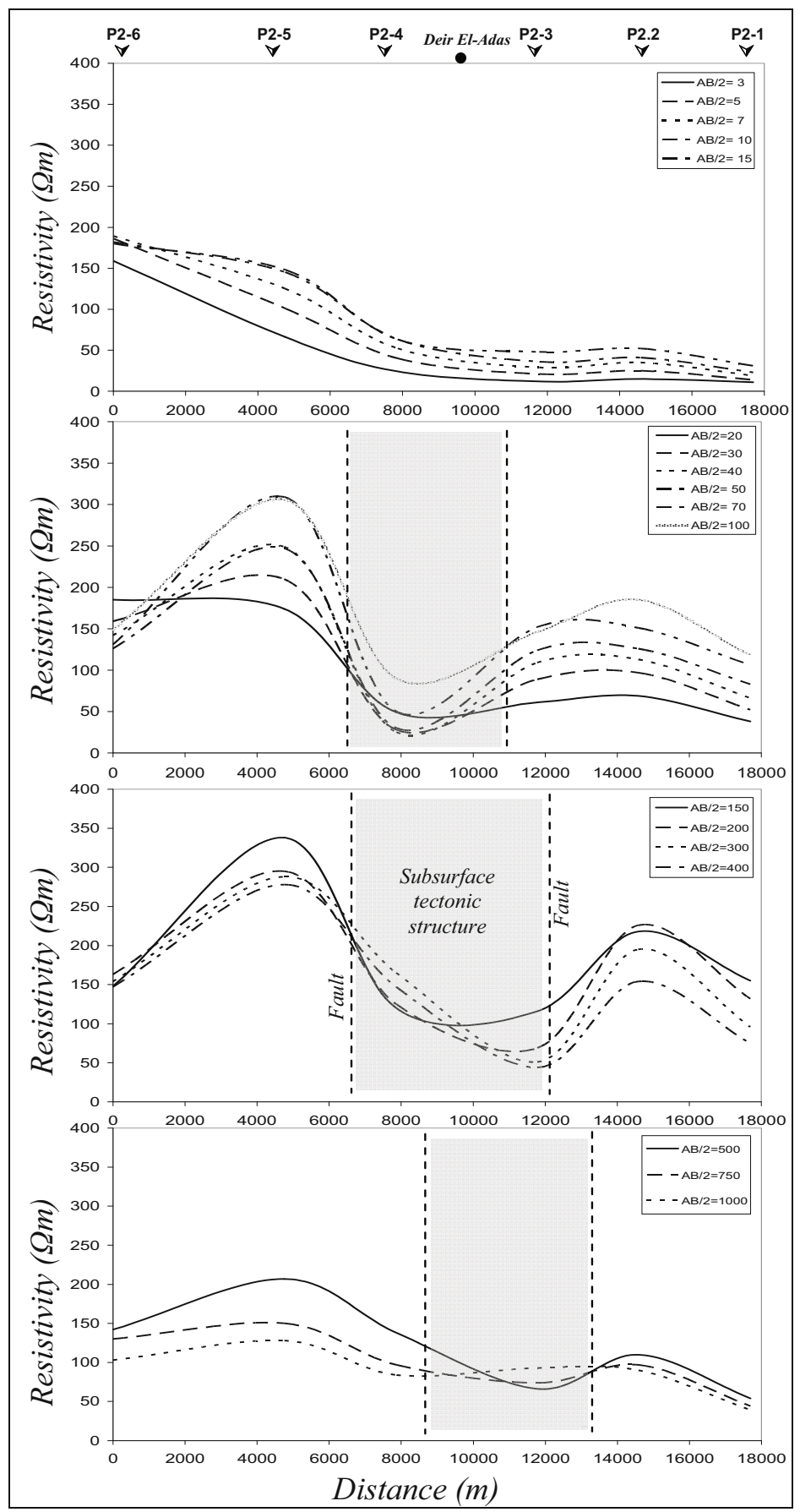

Fig. 4. Interpretation of the electrical resistivity profiling along the $\mathrm{P} 2$ profile. 

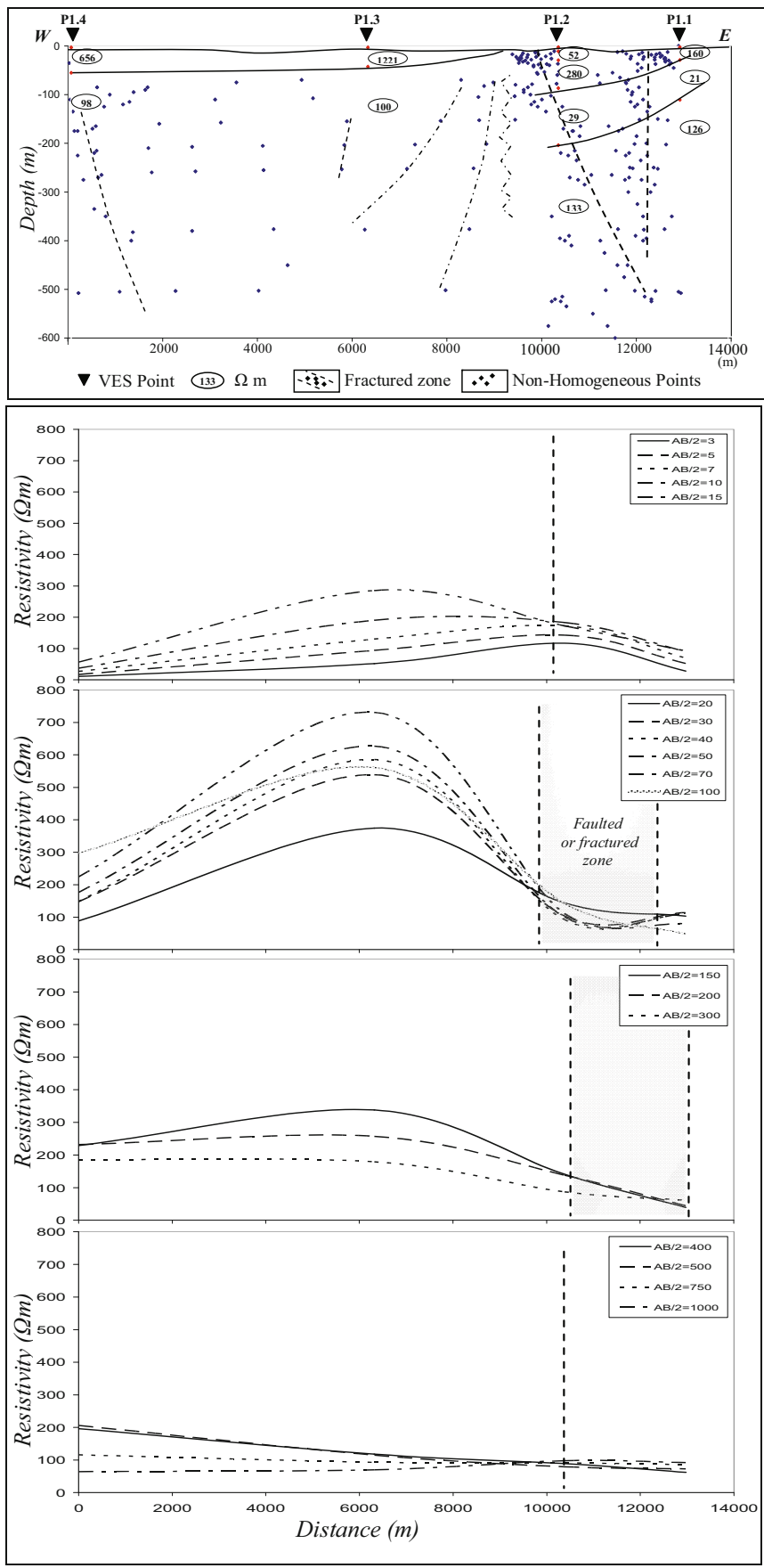

Fig. 5. Interpretation of the geoelectrical cross-section and profiling of the P1 profile. 


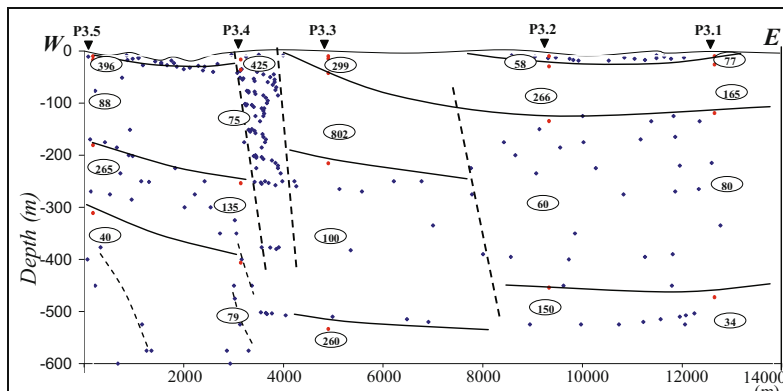

$-\mathbf{i}$ Faulted or fractured zone --- Uncertain limit $\square$ Litological limit $\begin{array}{llll}\nabla \text { VES Point } & \Omega \mathrm{m} & \because & \text { Non-Homogeneous Points }\end{array}$

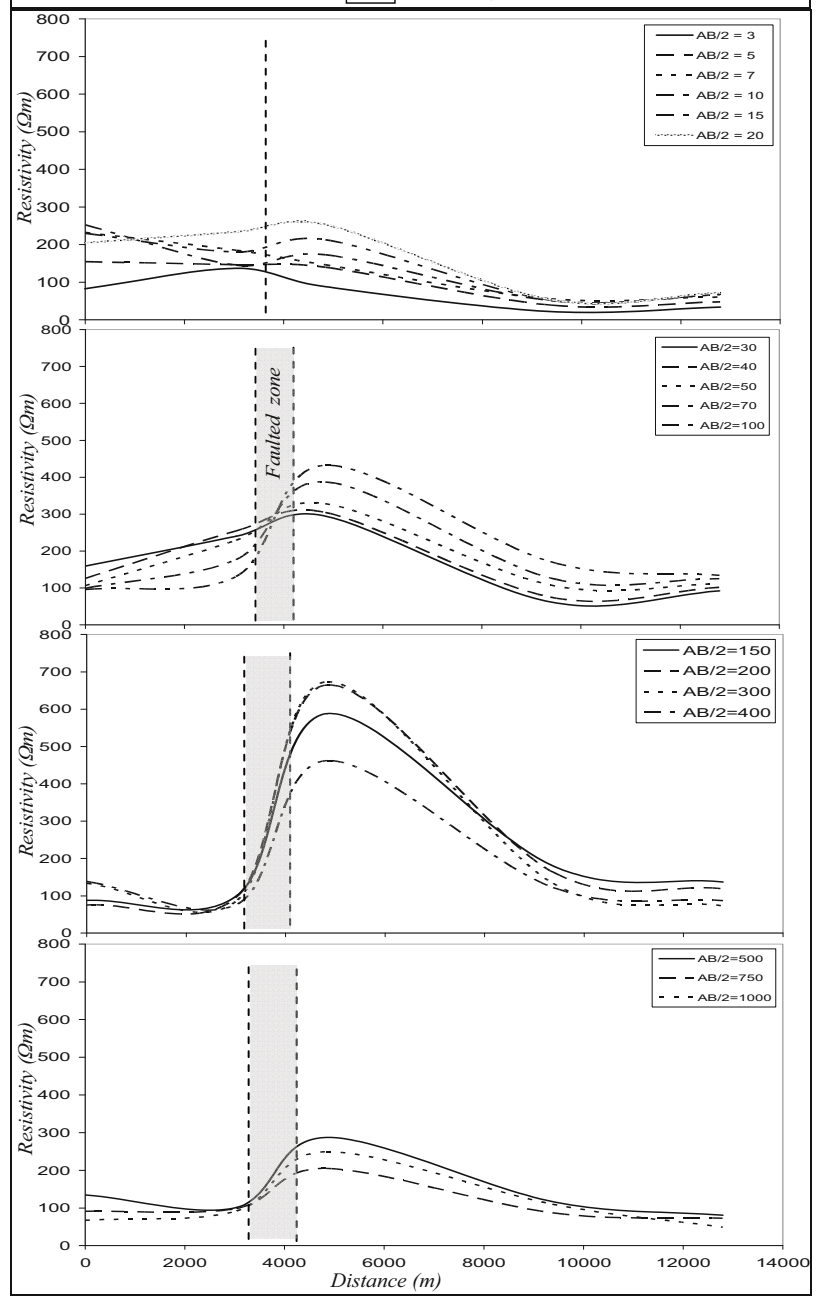

Fig. 6. Interpretation of the geoelectrical cross-section and profiling of the P3 profile. 


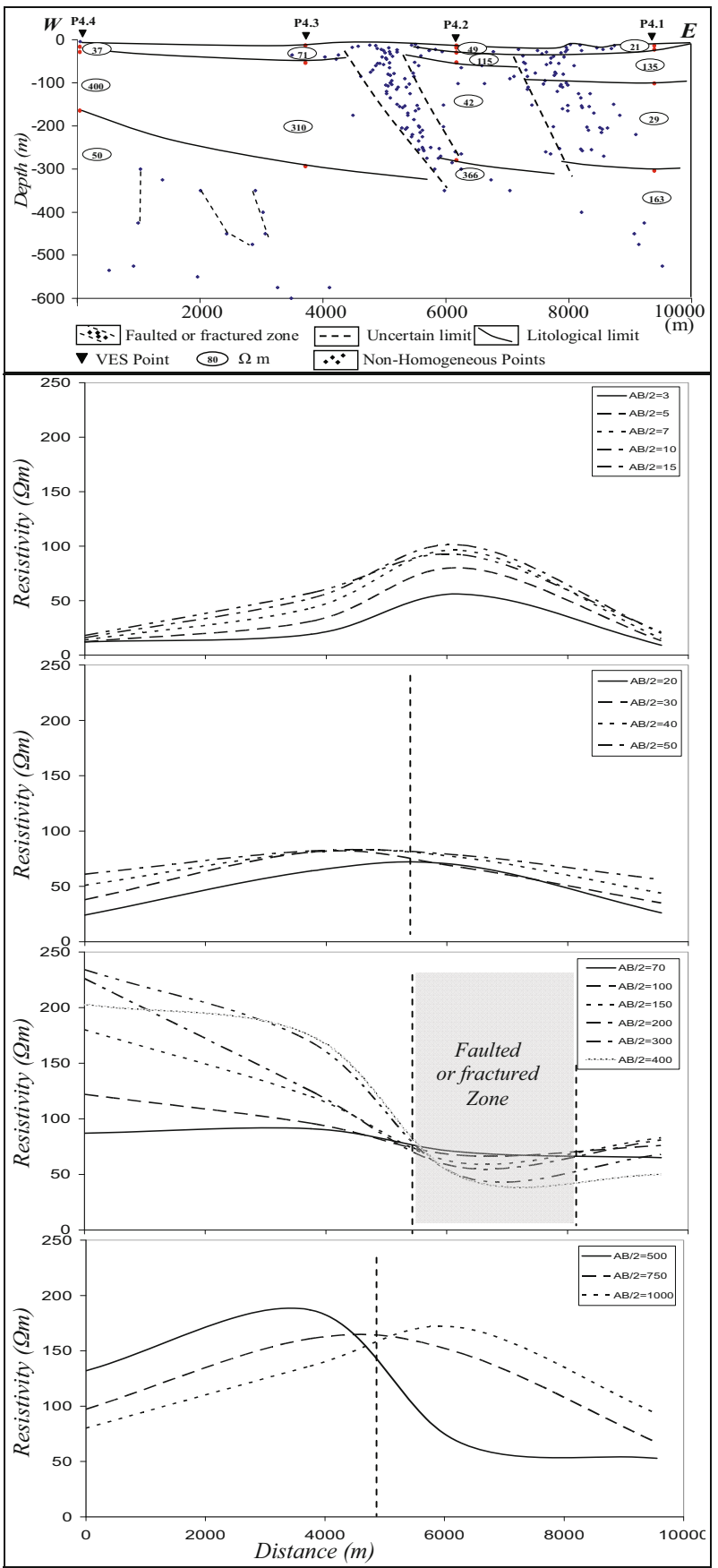

Fig. 7. Interpretation of the geoelectrical cross-section and profiling of the $\mathrm{P} 4$ profile. 
could be associated with Al-Hamyyan valley, which occurred through the curves of the electrical resistivity profiling $(A B / 2=70 \sim 400 \mathrm{~m})$, while the other might be a reflection of a subsurface deformed structure within the basaltic rocks. According to the interpretation of pseudo-section profiles and electrical profiling, evident differences can be noticed between the general structure of the $\mathrm{P} 1, \mathrm{P} 3$, and $\mathrm{P} 4$ profiles, and $\mathrm{P} 2$ profile structure that is characterized by the presence of a local subsurface anticline appeared underneath Deir El-Adas village. This distinguished structure and the associated faults are most likely to be responsible for the hydrogeological complexity in the study area and consequently led to the weakness of the groundwater aquifers around Deir El-Adas village.

Concerning the hydrogeological survey, the investigations of the drilled wells in the study area included more than 50 wells, most of which were examined and some others were excluded because they were under exploitation and it was not possible to execute the measuring. The joint interpretation of both geological and hydrogeological maps provided remarkable information (Fig. 8a):

- The direction of groundwater flow in the study area is compatible with the regional groundwater flow of the Yarmouk Basin, which has a general northwest-southeast trend.

- The presence of a watershed zone to the north-west of Deir El-Adas is compatible with the division of the Al-Arram valley into two branches. The presence of this watershed zone is likely to be related with a deep and complex faulted structure, which led to the hydrogeological isolating of the Deir El-Adas region. These findings confirm the results obtained by the geoelectrical investigations.

On the other hand, and in order to support the above-mentioned hydrogeological results, a discharge map (Fig. 8b) was performed for some available wells, based on the data derived from the General Company for Water Studies (1998). The results of the discharge map reveal that most of the wells drilled around Deir El-Adas area have a feeble water productivity or have failed. Where the discharge in Deir El-Adas village does not exceed $1.5 \mathrm{~L} / \mathrm{s}$, while it reaches more than $5 \mathrm{~L} / \mathrm{s}$ in the near vicinity of the village, especially towards south-west direction. Accordingly, the groundwater aquifers around Deir El-Adas area are marked by limited potential productivity due to the complexity of the particular geologic and tectonic settings.

In view of that, it can be concluded that drilling of a successful well in Deir El-Adas area is neither practical nor safe from hydrogeological point of view, at least within the basaltic rocks, which are the main formation in the area. This was confirmed by a well drilled to the east of Deir El-Adas village 

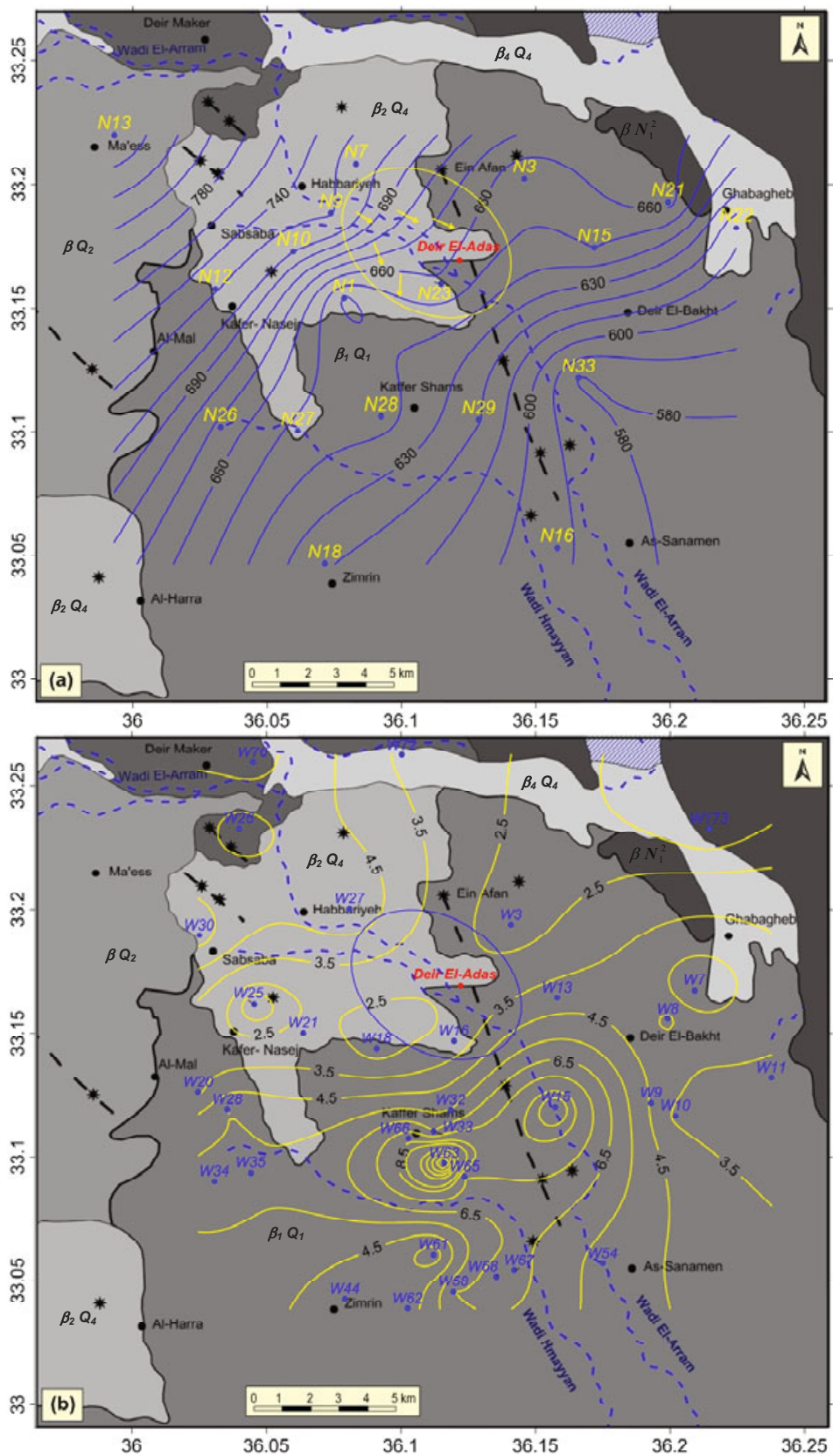

Fig. 8. Contour maps showing: (a) piezometric lines of the groundwater flow, where the yellow arrows indicate a watershed zone at the north-west of Deir El-Adas village, and (b) discharge rate lines (in L/s), where a feeble productivity is noted around Deir El-Adas. 
for water supply, which failed even though the depth of drilling reached the boundary between the basalts and the Paleogene surface at $200 \mathrm{~m}$ depth. Moreover, the defined boundary matches the depth inferred by the geoelectrical survey executed on the $\mathrm{P} 2$ profile, especially below the (P2.3) point, which may aid calibrating the geoelectrical dataset.

\section{CONCLUSION}

The results of the geoelectrical survey carried out in Deir El-Adas area indicated the presence of a complex tectonic substructure underlying the basaltic rocks at the top of the Paleogene formations. The recognized structure represents a geological anticline bounded by a group of faults, which led to a complex hydrogeological situation. The results also revealed the role of some blocking faults that prevent the regional groundwater recharge to the concerned area. This is the most probable cause responsible for the failure of the majority of the wells drilled in Deir El-Adas area. On the other hand, the results of the hydrogeological survey, represented by the piezometric and discharge maps, revealed the presence of a watershed associated with such complicated tectonic setting, which led to a limited discharge capability throughout the study area. From a methodological point of view, the application of the Pichgin and Habibullaev and the geoelectrical profiling techniques proved their suitability in the assessment of the hydrogeological and tectonic setting, and thereby enhanced the results of VES data interpretation. Consequently, the present work confirmed that it is not feasible to drill exploitable wells at depth less than $200 \mathrm{~m}$ in the close vicinity of Deir El-Adas village.

Acknowledgment. The author would like to acknowledge Professor I. Othman, Director General of the Atomic Energy Commission of Syria (AECS), for his constant support and encouragement. Thanks are also due to M. Al-Hilal, a colleague in the Department of Geology of AECS for his help. Thanks to A. Al-Ali and E. Soliman for their helps during the fieldwork. We also thank the municipality of Deir El-Adas in Daraa governorate for their technical supports in getting the necessary information of the drilled wells in the study area. 
Albouy, Y., P. Andrieux, G. Rakotondrasoa, M. Ritz, M. Descloitres, J.L. Join, and E. Rasolomanana (2001), Mapping coastal aquifers by joint inversion of DC and TEM soundings-three case histories, Ground Water 39, 1, 87-97, DOI: 10.1111/j.1745-6584.2001.tb00354.x.

Al-Fares, W. (2011), Contribution of the geophysical methods in characterizing the water leakage in Afamia B dam, Syria, J. Appl. Geophys. 75, 3, 464-471, DOI: 10.1016/j.jappgeo.2011.07.014.

Asfahani, J. (2007a), Electrical earth resistivity surveying for delineating the characteristics of ground water in a semi-arid region in the Khanasser Valley, northern Syria, Hydrol. Process. 21, 8, 1085-1097, DOI: 10.1002/hyp.6290.

Asfahani, J. (2007b), Geoelectrical investigation for characterizing the hydrogeological conditions in semi-arid region in Khanasser valley, Syria, J. Arid Environ. 68, 1, 31-52, DOI: 10.1016/j.jaridenv.2006.03.028.

Astier, J.L. (1971), Géophysique Appliquée à l'Hydrogéologie, Masson, 277 pp.

Bajbouj, M.K. (1982), Yarmouk basin (Syria), hydrological and hydrogeological studies, Ph.D. Thesis, National Institute and Polytechnic of Lorraine, France, 169 pp. (in French).

Bernard, T.N., D.L. Campbell, and R.M. Senterfit (1998), Depth of the base of the Jackson aquifer, based on geophysical exploration, southern Jackson Hole, Wyoming, USA, Hydrogeol. J. 6, 3, 374-382, DOI: 10.1007/ s100400050160.

Broadbent, M., and P.F. Callander (1991), A resistivity survey near Waimakariri River, Canterbury Plains, to improve understanding of local groundwater flow and of the capabilities of the survey method, New Zeal. J. Geol. Geophys. 34, 4, 441-453, DOI: 10.1080/00288306.1991.9514482.

Charideh, A.R., and Y. Jubeli (2001), Application of isotope study of the hydrogeological aquifer of the Yarmouk basin, Final Report on Scientific Research, Department of Geology, AECS-G\FRSR, 235 pp.

Chouker, F. (1986), Geophysical and hydrogeological study to western slops of Djebel Al-Arab (Al-Arab Mountain), Geol. Sci. Rev. Damascus Univ. 1, 13-21 (in Arabic).

Dobrin, M.B. (1976), Introduction to Geophysical Prospecting, McGraw-Hill, New York.

Dubertret, L. (1929), Etudes des régions volcaniques du Haouran, du Djebel Druze et du Diret et Touloul (Syrie), Reo. Gèogr. Phys. Gèol. Dynam. 2, 275-321 (in French).

General Company for Water Studies (1998), Project of hydrogeological investigations of Yarmouk basin, Ministry of Irrigation, General directorate of Yarmouk basin, General Company for Water Studies, Homs, Syria, 131 pp. 
Guerin, R., M. Descloitres, A. Coudrain, A. Talbi, and R. Gallaire (2001), Geophysical surveys, for identifying saline groundwater in the semi-arid region of the central Altiplano, Bolivia, Hydrol. Process. 15, 17, 3287-3301, DOI: 10.1002/hyp.284.

Kattan, Z. (1995), Chemical and environmental isotope study of the fissured basaltic aquifer systems of the Yarmouk Basin (Syrian Arab Republic). In: Symp. Isotopes in Water Resources Management, 20-24 March 1995, Vienna, Austria, IAEA-SM-336/28, 3-27.

Kelly, W.E., and S. Mares (eds.) (1993), Applied Geophysics in Hydrogeological and Engineering Practice, Elsevier, Amsterdam, 231 pp.

Orellana, E., and H.M. Mooney (1972), Two and Three Layer Master Curves and Auxiliary Point Diagrams for Vertical Electrical Sounding using Wenner Arranging, Interciencia, Madrid.

Pichgin, N.I., and I.K.H. Habibullaev (1985), Methodological recommendations in studying geo-tectonic conditions of vertical electrical soundings data with application of EC computer for solving hydrogeological and geoengineering problems, Tashkent (in Russian).

Ponikarov, V. (1963), Geological map of Syria, 1:200 000, I-36-XII, I-37-VII sheet, V.O. Technoexport. Ministry of Industry, Damascus, Syria.

Reynolds, J.M. (1997), An Introduction to Applied and Environmental Geophysics, John Wiley \& Sons, Ltd., 806 pp.

Safadi, C. (1956), Hydrogéologie des terrains volcaniques de la Syrie méridionale (Haurane), Ph.D. Thesis, Faculte des Science, Université Nancy, France.

Salameh, E., and M. Al Farajat (2007), The role of volcanic eruptions in blocking the drainage leading to the Dead Sea formation, Environ. Geol. 52, 3, 519527, DOI: 10.1007/s00254-006-0484-X.

Sandberg, S.K., L.D. Slater, and R. Versteeg (2002), An integrated geophysical investigation of the hydrogeology of an anisotropic unconfined aquifer, J. Hydrol. 267, 3-4, 227-243, DOI: 10.1016/S0022-1694(02)00153-1.

Selkhozprom Export (1982), Report on hydrological and hydrogeological surveys for the development scheme of water resources in Yarmouk River Basin, Syrian Arab Republic. Vol. II. Hydrogeological and engineering geological condition, Selkhozprom Export, Moscow, 228 pp.

Vouillamoz, J.-M., J. Hoareau, M. Grammare, D. Caron, L. Nandagiri, and A. Legchenko (2012), Quantifying aquifer properties and freshwater resource in coastal barriers: a hydrogeophysical approach applied at Sasihithlu (Karnataka state, India), Hydrol. Earth Syst. Sci. 16, 4387-4400, DOI: 10.5194/ hess-16-4387-2012.

Wilson, S.R., M. Ingham, and J.A. McConchie (2006), The applicability of earth resistivity methods for saline interface definition, J. Hydrol. 316, 1-4, 301312, DOI: 10.1016/j.jhydrol.2005.05.004. 
Yadav, G.S., P.N. Singh, and K.M. Srivastava (1997), Fast method of resistivity sounding for shallow groundwater investigations, J. Appl. Geophys. 37, 1, 45-52, DOI: 10.1016/S0926-9851(97)00009-8.

Zarroca, M., J. Bach, R. Linares, and X.M. Pellicer (2011), Electrical methods (VES and ERT) for identifying, mapping and monitoring different saline domains in a coastal plain region (Alt Empordà, Northern Spain), J. Hydrol. 409, 12, 407-422, DOI: 10.1016/j.jhydrol.2011.08.052.

Zohdy, A.A.R. (1989), A new method for the automatic interpretation of Schlumberger and Wenner sounding curves, Geophysics 54, 2, 245-253, DOI: 10.1190/1.1442648.

Received 1 July 2014

Received in revised form 17 February 2015

Accepted 4 May 2015 